\title{
The Camp Dodger: A Military Newspaper of the First World War
}

The Camp Dodger was published weekly at Camp Dodge, Iowa, and later in France, during and shortly after the First World War. A complete file of the Camp Dodger, including all United States and overseas issues, is owned by The University of Iowa Libraries. This is probably the only complete set of the paper in Iowa, and may indeed be the only complete set in any institution in the United States. ${ }^{1}$ While official and semiofficial military newspapers are not unusual, the Camp Dodger is a special and interesting case; it is special because of the scarcity of complete collections, and interesting because of its potential research value and the story behind its publication.

The Camp Dodger emerged on September 21, 1917, at Camp Dodge as an official publication of the 88th Infantry Division, a unit composed largely of draftees from the Midwest and forming part of the National Army. Editor-in-chief of the paper was Laurence R. Fairall, a former newspaperman who is now a retired advertising executive in Des Moines, Iowa. ${ }^{2}$ Other early staff members were also soldiers, working to put out the paper in addition to their military duties. Later, when demand for the Camp Dodger exceeded the abilities of a parttime staff, several civilians were added.

The quality and variety of news content in the Camp Dodger are greater than one would expect in a military newspaper, and they are

${ }^{1}$ An inquiry to the Union Catalog Division of the Library of Congress brought the reply that the Camp Dodger was held only by the Library of Congress. The Library of Congress Catalog of Printed Cards, vol. 24, p. 149, cites the U.S. edition only, then continues with the note, "An Overseas edition of the Camp dodger [sic] was issued in the Gondrecourt area, France, beginning with the Feb. 3, 1919 (v. 2, no. 1). No more published?" This suggests that the Library of Congress does not hold all issues of the overseas edition and is unaware of the date when publication was terminated.

${ }^{2}$ Mr. Fairall is the donor of part of The University of Iowa Camp Dodger collection. 
worth discussing at some length as indications of the range of research possibilities in the paper. Anyone pursuing the careers of Iowa journalists, for example, would find a regular column, "Little Stories of Camp Dodge," by Ruth Stewart of the Des Moines Register. Irving N. Brant, also of the Register, provided a weekly column of war news, R. W. Douglas drew cartoons, Edward S. Howes, the feature editor, also contributed a poetry column, and Dorothy Ashby, of the Des Moines Daily Capital, did incidental pieces. ${ }^{3}$

The entertainment page, supervised by drama editor William W. Kane, deserves special mention since the paper heavily reported entertainment news. Stories were written about virtually every performer or program appearing in Des Moines or Camp Dodge, and motion pictures were advertised in every issue. When the Liberty Theater opened at Camp Dodge on December 2, 1917, the Camp Dodger noted that it was the largest motion picture house in Iowa, seating three thousand people. ${ }^{4}$ According to advertisements, the Liberty offered the films of William S. Hart, Fatty Arbuckle, Douglas Fairbanks, Mary Pickford, and others, in an attempt to provide a place for soldiers to “. . . feel at home, enjoy a smoke, and see a good clean show. . .."5 Later the paper reported that the name of the theater had been changed to The Trilby to avoid confusion with the official army amusement halls, named "Liberty Theaters" by President Wilson. ${ }^{6}$

Service organizations also contributed to the entertainment at Camp Dodge. On one occasion, the Camp Dodger reported that over two thousand men attended a Knights of Columbus vaudeville show starring Des Moines club women. ${ }^{7}$ The YMCA offered a similar range of entertainment, including at least one performance by the Capital City Music Quartet, in which Jay N. Darling, the famous cartoonist, sang bass. $^{8}$

Sports, like entertainment, were given extensive coverage in the Camp Dodger. Among the several outstanding athletes in the 88th Division were Earl Caddock, the world's champion wrestler, ${ }^{9}$ Mike

\footnotetext{
3 Dorothy Ashby Pownall, "A Girl Reporter at Camp Dodge," Palimpsest, XLVII (June, 1966), pp. 225-256.

4 "Liberty Theater to Open Sunday," Camp Dodger, I (November 29, 1917), p. 5 .

5 Camp Dodger, I (November 16, 1917), p. 5.

6 "Liberty Moving Picture House Changes Name," Camp Dodger, I (December 21, 1917), p. 5 .

7 "K. of C.s' Stage Best Show of Season Monday," Camp Dodger, I (December $21,1917)$, p. 5.

8 "Des Moines Artists Who Will Entertain Soldiers at Camp Dodge During the Long Winter Evenings," Camp Dodger, I (October 12, 1917), p. 4.

9 "Earl Caddock Retains World Wrestling Title," Camp Dodger, I (December $14,1917)$, p. 8.
} 
Gibbons, the world middleweight boxing champion; ${ }^{10}$ and welterweight boxer Labe Safro. ${ }^{11}$ Athletic programs at Camp Dodge were under the charge of John L. Griffith, former athletic director at Drake University. ${ }^{12}$ Special emphasis was given to any sport with a military application, ${ }^{13}$ and a series of boxing lessons for soldiers was illustrated with photographs. Sports news normally filled an entire page.

Less regular than sports and entertainment news, but probably just as frequent, were articles about individual soldiers. A researcher working on the life of any notable individual who served at Camp Dodge would almost certainly find some mention of him in the Camp Dodger. In one issue, for example, are stories about Arthur Zeller, a Peoria, Illinois, millionaire, joining the Division as a private, ${ }^{14}$ and Major George M. Lee, son of Confederate Major General Fitzhugh Lee, taking command of an infantry regiment. ${ }^{15}$ Other stories discuss the background and special talents of soldiers at Camp Dodge, or relate anecdotes about their activities.

Another thoroughly reported topic was the impact of Camp Dodge on the city of Des Moines. This impact would seem to have been frequently manifested by the energetic anti-vice work of civilian and military officials in ". . . making moral conditions surrounding Camp Dodge cleaner than anywhere in the country."16 Reports of this concern for the moral condition of the military also appeared in the civilian press. ${ }^{17}$ More mundane topics also warranted attention, and the crisis in inter-urban transportation was described in both the Camp Dodger $^{18}$ and the Register. ${ }^{19}$ Inter-urban officials purchased space in the Camp Dodger to explain the reasons for transportation short-

\footnotetext{
10 "Brothers Meet for World Title," Camp Dodger, I (October 5, 1917), p. 4.

11 "Former Boxer Now at Camp," Camp Dodger, I (October 5, 1917), p. 4.

12 "Former Drake Coach at Camp," Camp Dodger, I (September 28, 1917), p. 4.

13 "Soldiers Will Be Taught Jiu Jitsu," Camp Dodger, I (September 21, 1917), p. 4 .

14 "Millionaire Is Now Stationed at Camp Dodge," Camp Dodger, I (October 26,1917 ), p. 1.

15 "Son of Famous General Lee Is Now at Camp Dodge," Camp Dodger, I (October 26, 1917), p. 1.

16 "Keeping D.M. Clean," Camp Dodger, I (January 11, 1918), p. 1.

17 "Bootleggers Due for More Trouble," Des Moines Register, LXIX (September 28, 1917), p. 4.

18 "No Relief from Present Inter-urban Service," Camp Dodger, I (October 5, 1917 ), p. 1.

19 "Train Service to Camp Overtaxed," Des Moines Register, LXIX (September 27,1917 ), p. 5.
} 
comings ${ }^{20}$ and to advertise new service and special trains for Camp Dodge. $^{21}$

The inter-urban advertisements exemplify the concern of the Camp Dodger staff to adjust advertising as well as news content to the interests of the enlisted soldier. The enterprising advertising manager, E. Lee Kayser, was one of the civilians hired to work full time. The paper contained many advertisements from Des Moines merchants, and Mr. Kayser was active in promoting good-will advertising from firms whose former employees served in the 88th Division. Advertising combined with sales to make the Camp Dodger a profitable enterprise. Circulation reached forty thousand copies on July 25, 1918, ${ }^{22}$ and, during the first year of publication, $\$ 26,000$ were turned over to the Division Athletic Fund as surplus profits. ${ }^{23}$

In addition to the content of news and advertising, expressions of opinion and the use of slang terms in the Camp Dodger help reveal the concerns, attitudes, and common speech of the Midwestern soldier. In several articles, for example, training, recreational, and even disciplinary activities concerning Afro-American soldiers at Camp Dodge are reported clearly and factually. ${ }^{24}$ In humor columns, on the other hand, racial and ethnic slang and dialect often appear, ${ }^{25}$ and there was definitely a negative editorial opinion of civilians unwilling to support the war effort.

The war has discovered a new species. He presents some of the characteristics of the obstructionist, but has not his perseverance. His lack of courage prevents him from becoming a radical, and he hasn't convictions strong enough, erroneous though they may be, to make him a socialist, so he slips along, following the line of least resistance, and becomes a slacker. ${ }^{26}$

These examples of subject matter and tone of material in the Camp Dodger are illustrative of the paper throughout its life.

The Camp Dodger continued as the official paper of the 88th Division until the Division left Camp Dodge for France. The issues of

20 Camp Dodger, I (November 9, 1917), p. 2.

21 Camp Dodger, I (December 21, 1917), p. 4.

22 "The Camp Dodger," Camp Dodger, I (July 26, 1918), p. 4.

23 "A Year of Achievement," Camp Dodger, II (September 20, 1918), p. 4.

24 "Cold Has Very Little Effect on the Negroes," Camp Dodger, I (December 28, 1917), p. 6; "A New Regiment of Colored Men Organized Here," Camp Dodger, I (June 28, 1918), p. 7; "Three Negroes Hang at Camp As Penalty for Assaulting Girl," Camp Dodger, I (July 5, 1918), p. 1.

25 "Gas Bombs," Camp Dodger, I (April 19, 1918), p. 4; also I (May 24, 1918), p. 4.

26 "The Slacker," Camp Dodger, I (June 14, 1918), p. 4. 
this period ran from four to sixteen pages. They covered September 21, 1917, to August 16, 1918, and were numbered volume I, numbers 1-48. As one of the first 88th Division men to go overseas, Lt. Fairall was dropped as editor-in-chief after volume I, number 46, on August 2,1918 , and the position was not continued.

Beginning with volume I, number 49, on August 23, 1918, the paper assumed the designation "Official Paper of the U.S.A. Forces at Camp Dodge." Lawrence H. Martin, the managing editor, directed the work of a combined military and civilian staff. The second year of publication began with volume II, number 1, on September 20, 1918. In several stages, the paper reduced its number of pages and physical size until the terminal issue of the United States edition, volume II, number 20, which appeared on January 31, 1919. Dwindling numbers of soldiers at Camp Dodge had decreased the income of the Camp Dodger so much that it could not support its staff. ${ }^{27}$

Shortly after the termination of the United States edition, an overseas edition of the Camp Dodger was begun. The 88th Division had been training and fighting from its arrival in France in September, 1918, until after the armistice in November, 1918. With the end of the fighting, the Division command developed a concern for troop morale and decided to revive the Camp Dodger as a source of information and amusement. Lt. Fairall was established in a subsection of Division Intelligence and assigned full time to reorganizing the paper ${ }^{28}$ Riding around the Division area near Gondrecourt on a horse, he recruited former and new staff members and searched for equipment and facilities. A print shop was found at Bar-le-Duc, while editorial offices remained at Division Headquarters in Gondrecourt for the life of the European edition.

The print shop was rather a mixed blessing. The Germans had blown a hole in the roof, there was no electrical power, and the old flat-bed press was operated in a curious but ingenious manner.

Two ropes were tied to an iron spoke of the wheel. On one of these ropes an old doddering man and a little girl attached themselves. The other rope was grasped by a strong young woman. The old man and the child pulled and the wheel turned half way. The young woman, stationed on the opposite side, pulled and it turned the other half. Then the old man and the child pulled again while the young woman let her rope go slack. So the press was turned over. ${ }^{29}$

27 “Camp Dodger Discontinued This Edition," Camp Dodger, II (January 21, 1919), p. 1 .

${ }^{28}$ Interview with Laurence R. Fairall, November 14, 1968.

29 "Dodger Born 'mid Trouble and Woe," Camp Dodger, II (February 10, 1919), p. 2. 
A shortage of newsprint caused the first issues of the overseas Camp Dodger to be printed on book paper acquired from the stock of the French printer. All type was hand set, but fortunately for the soldiertypesetters the French type trays were arranged in the same manner as their American counterparts. There was, however, a shortage of the letter "w," which occurs less frequently in French than in English. For this reason, the issues of the paper printed at Bar-le-Duc are distinguished not only for their excellent paper, but also by frequent use of upside-down "m's," for "w's".

The first overseas issue of the Camp Dodger, numbered volume II, number 1, appeared on February 3, 1919. This numbering duplicated that of the United States edition, which had begun a volume II on September 20,1918, and may account for the incomplete entry in the Library of Congress Catalog of Printed Cards..$^{30}$ Printing continued weekly at Bar-le-Duc until volume II, number 3, on February 17, 1919. Then facilities were found in Paris. The move to Paris was necessary because the demand for the Camp Dodger exceeded the facilities of the small shop. Its maximum capacity was fifteen thousand copies a week, and there was no equipment to print photographs or other illustrations. ${ }^{31}$

A Paris firm, Société Anonyme des Imprimeries Wellhoff et Roch, was engaged to print an enlarged Camp Dodger ${ }^{32}$ The first issue printed in Paris, volume II, number 4, appeared on February 24, 1919. It was four pages, on newsprint, with photographs and other illustrations. Advertisements from both French and American firms came out in the second Paris issue and continued to increase in number. The paper grew to eight pages with volume II, number 10, on April 7, 1919.

The expansion of the Camp Dodger extended to fields beyond weekly journalism. In addition to channeling its profits to the Division Athletic Fund, the paper provided some of the financing for the Division variety show, "Who Can Tell?"33 Other Camp Dodger activities which warrant mention if not lengthy discussion include a Paris Shopping Service, ${ }^{34}$ a Soldiers' Service Bureau for postwar employment, ${ }^{35}$ and an Overseas News Service for United States newspapers. ${ }^{36}$

\footnotetext{
${ }^{30}$ See footnote one.

31 "Go Easy!" Camp Dodger, II (February 10, 1919), p. 1.

32 Camp Dodger, II (February 24, 1919), p. 4.

${ }^{33}$ Interview with Laurence R. Fairall, November 14, 1968. A program from "Who Can Tell?" is among the Camp Dodger materials at The University of Iowa. ${ }^{34}$ Camp Dodger, II (April 21, 1919), p. 5.

35 "Camp Dodger Opens Soldiers' Service Bureau for the Men Who Want Jobs When Discharged," Camp Dodger, II (April 7, 1919), p. 1.

${ }^{36}$ A mimeographed two-page bulletin, "By the Overseas Camp Dodger News
} 
This variety of activities of the Camp Dodger staff was halted by the decision to return the 88th Division to the United States for demobilization. The last issue printed in Paris, volume II, number 14, appeared on May 5, 1919. A box on the front page carried a notice that publication would be suspended for two weeks, then an attempt would be made to resume at Le Mans where, apparently according to rumor, the Division was to be moved. That, however, was not to be, and the best information now available ${ }^{37}$ indicates that the next, and last, issue of the Camp Dodger did not appear until May 28, 1919. It was a single "on-the-seas" edition, a four-page leaflet on book paper, numbered volume III, number 1 . Soldiers of the 88th Division hand set the issue aboard the Pocahontas, a troopship carrying them back to the United States.

This last issue completes the Camp Dodger collection at The University of Iowa so far as the paper itself is concerned. Continued efforts are being made, however, to locate former staff members and to gather correspondence and other background material to enrich the collection. Meanwhile all issues of the Camp Dodger have been microfilmed and the paper is currently available for scholarly use.

Service" dated January, 1919, is among the Camp Dodger materials at The University of Iowa.

37 Interview with Laurence R. Fairall, November 14, 1968. 


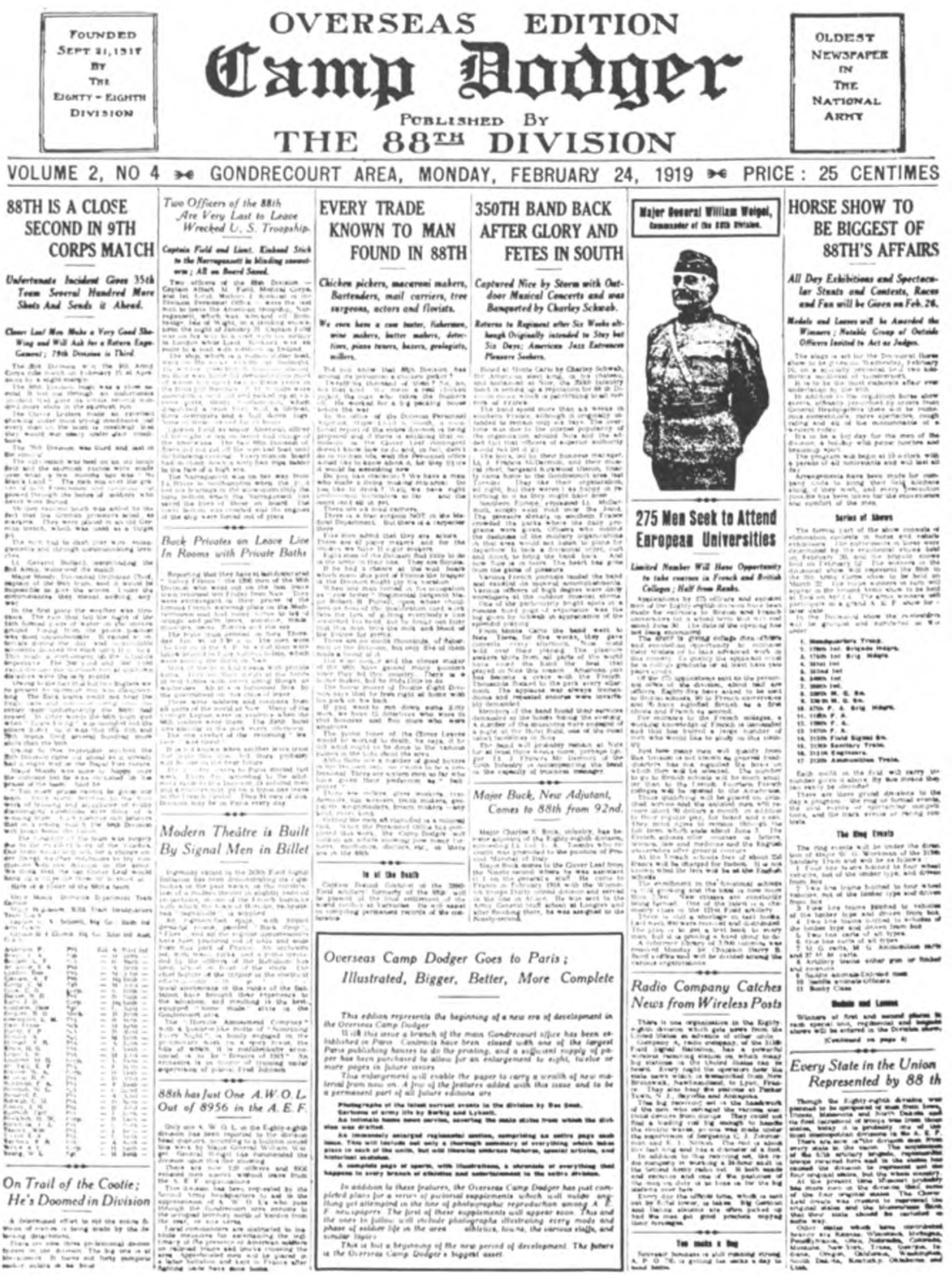

Front page of the February 24, 1919, issue of the Camp Dodger, a military newspaper of the First World War. 